\title{
The History and Economics of Melaleuca Management in South Florida ${ }^{1}$
}

Katherine Carter-Finn, Alan W. Hodges, Donna J. Lee, and Michael T. Olexa ${ }^{2}$

An invasive species, as defined in 1999 by

Presidential Executive Order 13112, is "an alien species whose introduction does or is likely to cause economic or environmental harm or harm to human health." Alien or invasive species have affected many, if not most, countries around the world in some way. In some cases, these non-native species have been purposefully introduced for bona fide reasons such as ornamental decoration, erosion control, and livestock forage. In other situations, alien species have been inadvertently introduced. This is occurring more frequently, largely due to increased global travel. Some alien species are introduced and remain rather innocuous over time. However, often times they can cause devastating and irreversible consequences.

Florida's sub-tropical environment, with mild winters and warm wet summers, is hospitable to a wide variety of temperate and tropical plants and animals. Thus there is an enormous potential for non-native species to become naturalized to ecosystems within the State.

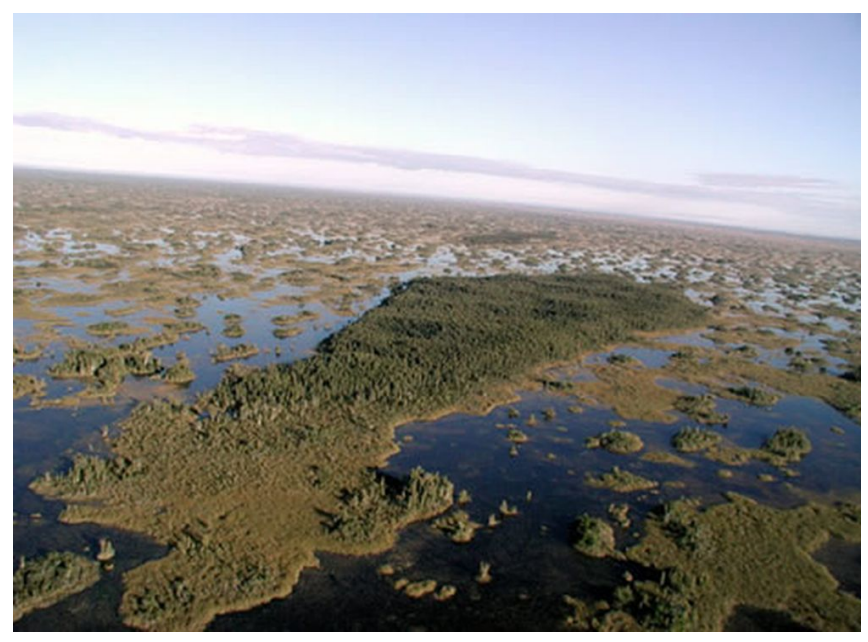

Figure 1. Melaleuca infestation on tree-island in Loxahatchee NWR FL(TAME 2006).

\section{Melaleuca}

One especially destructive invasive species is the tree commonly known as Melaleuca (Melaleuca quinquenervia). This species is thought to have been introduced into Florida in Manatee County around 1887. The tree was popularized by nurseries to provide shade and windbreaks for home owners, and it gained recognition for its ability to thrive in both upland and aquatic environments (Serbesoff-King

1. This is EDIS document FE670, a publication of the Food and Resource Economics Department, Florida Cooperative Extension Service, Institute of Food and Agricultural Sciences, University of Florida, Gainesville, FL. Published November 2006. Please visit the EDIS website at http://edis.ifas.ufl.edu.

2. Katherine Carter-Finn, graduate student; Alan W. Hodges, Assocate In; Donna J. Lee, Associate Professor; and Michael T. Olexa, Professor; Food and Resource Economics Department, Florida Cooperative Extension Service, Institute of Food and Agricultural Sciences, University of Florida, Gainesville, FL. 
2003). In 1941, the U.S. Army Corps of Engineers

(USACE) began planting Melaleuca trees in the Lake Okeechobee area along levees and spoil islands for erosion control (Stocker and Sanders 1981).

Melaleuca was planted in swampy areas under the belief that it would help dry these places and facilitate future development (Laroche and McKim 2004). This notion has been debated among scientific scholars: while some adhere to the belief that Melaleuca consumes more water than native vegetation, others argue that it does not use any more water than other plants.

Melaleuca has now become established in south Florida, and has spread much more quickly there than in its native Australia (Rayamajhi et al. 2002).

Current estimates place the coverage of Melaleuca in south Florida at anywhere from 200,000 to 500,000 acres (Figure 1). The main issue with Melaleuca is that it causes a reduction in area of uplands and ecologically-sensitive wetland areas. Due to its rapid growth and reproduction rates, Melaleuca may completely dominate landscapes that it invades, thus decreasing biodiversity and precluding the growth of native vegetation (Schmitz and Hofstetter 1999).

Studies show that patches of Melaleuca can spread to dominate one square mile of land in only 25 years (Laroche and Ferriter 1992). Melaleuca may also increase wildfire danger because the dense stands burn with greater intensity, making fire control more difficult (Diamond et al. 1991).

\section{Economic Damages}

A general estimate of the value of environmental and economic services provided by wetlands is $\$ 14,785$ per hectare, per year (Costanza et al. 1997). Assuming minimal losses of 1 percent of this value per hectare and a current infestation of 200,000 hectares, the diminished value would be almost $\$ 30$ million per year. Farmers and ranchers are losing valuable grazing and crop land, while natural areas such as parks/preserves are losing natural habitats, which in turn affect plant and animal diversity. Melaleuca invades utility easements, such as power lines, canals, and other waterways, thus impairing their use, and often makes costly tree removal necessary to maintain the use of these service areas. It has been projected that the unfettered spread of this plant would severely limit the use of parks and recreational areas by tourists and residents, causing a negative impact to the Florida economy of $\$ 160$ million annually (Diamond et al. 1991). Early studies suggested that by the year 2010, an estimated $\$ 1.76$ billion in damages would be caused due to the various negative impacts Melaleuca has on recreation, ecotourism, fires, and loss of endangered species (Balciunas and Center 1991).

\section{Management History}

Control of Melaleuca in Florida was not seriously pursued until the late 1980s, under the mandate to restore the Everglades. During the 1990s, the framework was created for the Comprehensive Everglades Restoration Plan (CERP), which encompassed the eradication of exotic invasives within that ecosystem. In 2000, the Water Resources Development Act of 2000 was enacted, authorizing the CERP. The Melaleuca Eradication and Other Exotic Plants project within the CERP was designed to address exotic and invasive species management and control in south Florida (CERP 2004). In 1993, the Florida legislature enacted statutes that required agencies such as the Florida Department of Environmental Protection, Bureau of Invasive Plant Management (FDEP-BIPM) to investigate methods for control of Melaleuca and to implement those controls within their jurisdiction (FS 369.252). Under current state law, it is illegal to sell, transport, collect, cultivate, or possess any plant, including any part or seed of the species Melaleuca quinquenervia, without a permit from the FDEP or the Florida Department of Agriculture and Consumer Services (FS 369.251). A subsequent law in 1997 directed the Bureau of Invasive Plant Management (BIPM) to bring exotic upland species under "maintenance control", which is defined as "a method for the control of non-indigenous aquatic plants in which control techniques are utilized in a coordinated manner on a continuous basis in order to maintain the plant population at the lowest feasible level as determined by the department" (FS 369.22). The 1993 Florida legislature also set aside an annual budget of $\$ 1$ million to the FDEP specifically for Melaleuca control. The FDEP entered into a cost-sharing program with the South Florida Water Management District (SFWMD), known as the Melaleuca 
Program, with the goal of controlling Melaleuca on all SFWMD land at the lowest possible infestation rates while minimizing impacts to non-target plant species. In order to prevent the further spread of the plant, outlying lesser infested areas were treated first according to a quarantine strategy (BIPM 2003). The goal of the FDEP is to reduce infestations of upland invasive exotic plants on public lands by 25 percent by the year 2010 based on the estimated 1995 level of infestation of 1.5 million acres (BIPM 2003). It should be noted that this estimated area is for all upland invasive species and not just Melaleuca.

The Areawide Management Evaluation of Melaleuca (TAME Melaleuca or TAME) was established under the auspices of the USDA Agricultural Research Service (ARS) Areawide Pest Management initiative to demonstrate the efficacy of an integrated approach for control of Melaleuca. This effort was tasked with implementing the recommendations of the Melaleuca Task Force as described in the Melaleuca Management Plan of the Florida Exotic Pest Plant Council (Pratt and Ferriter 2001). From 1989 to 1999, Florida agencies spent about $\$ 25$ million on its control and succeeded in reducing the area it covers on public land by about 100,000 acres (Pratt and Ferriter 2001).

\section{Conclusion}

While removal of Melaleuca is a mandate for public agencies, one of the remaining obstacles is that private landowners have generally not implemented control practices. While it is technically illegal for private individuals to possess Melaleuca, very little is actually being done to force them to remove it from their property, with the exception of a few proactive municipalities. Thus, while infestations of Melaleuca have declined on public lands, they are flourishing on private lands. These stands on private property may lead to new infestations or reinfestation in areas already treated, thus undermining public control efforts. A comprehensive strategy that includes private landowner incentives and enforcement is needed for inducing these landowners to adopt recommended control practices for Melaleuca.

\section{References}

Balciunas, J.K., and T.D. Center. 1991. Biological Control of Melaleuca quinquenervia: Prospects and Conflicts. Proceedings of the Symposium on Exotic Pest Plants, edited by T.D. Center, R.F. Doren, R.L. Hofstetter, R.L. Myers, and L.D. Whiteaker, pp. 1-22. NPS/NREVER/NRTR-91/06. Denver, CO: National Park Service.

Bureau of Invasive Plant Management (BIPM). 2003. Upland Invasive Exotic Plant Management Program Report. htp://www.dep.state.fl.us/lands/invaspec/2ndlevpgs/ pdfs/Uplands\%202002-2003.pdf (Accessed June 2004).

Comprehensive Everglades Restoration Plan (CERP). 2004. Central and Southern Florida Project. Comprehensive Everglades Restoration Plan. Project Management Plan: Melaleuca Eradication and Other Exotic Plants. http://www.evergladesplan.org/pm/pmp/pmp_docs/ pmp_95_melaleuca/092704_pmp_95_main_body.pdf (Accessed June 2005).

Costanza, R., R. dArge, R. de Groots, S. Farber, M. Grasso, B. Hannon, K. Limburg, S. Naeem, R.V. ONeill, J. Paruelo, G.G. Raskin, P. Sutton, and M. van den Belt. 1997. The Value of the World's Ecosystem Services and Natural Capital. Nature 387:253-260.

Diamond, C., D. Davis, and D.C. Schmitz. 1991. Economic Impact Statement: The Addition of Melaleuca quinquenervia to the Florida Prohibited Aquatic Plant List. Proceedings of the Symposium on Exotic Pest Plants, edited by T.D. Center, R.F. Doren, R.L. Hofstetter, R.L. Myers, and L.D. Whiteaker, pp. 87-110. NPS/NREVER/NRTR-91/06. Denver, CO: National Park Service.

Florida Statute 369.22, 251-.252. 2004. Title XXVIII-Natural Resources; Conservation, Reclamation, and Use. http://www.flsenate.gov/statutes/ (Accessed June 2005). 
Laroche, F.B., and A.P. Ferriter. 1992. The Rate of Expansion of Melaleuca in South Florida. Journal of Aquatic Plant Management 30:62-65.

Laroche, F.B., and J. McKim. 2004. Cost Comparison of Melaleuca Treatment Methods. South Florida Water Management District, West Palm Beach, FL.

http://www.sfwmd.gov/org/clm/lsd/mitigation/ cell_17_18/cost_comparison_of_melaleuca.html (Accessed February 2005).

Rayamajhi, M.B., T.K. Van, T.D. Center, J.A. Goolsby, P.D. Pratt, and A. Racelis. 2002. Biological Attributes of the Canopy-Held Melaleuca quinquenervia Seeds in Australia and Florida. Journal of Aquatic Plant Management 40:87-91.

Schmitz, D.C., and R.H. Hofstetter. 1999. Environmental, Economic and Human Impacts. Melaleuca Management Plan, Ten Years of Successful Melaleuca Management in Florida 1988-1998, edited by F. Laroche, pp. 17-21. Fort Lauderdale, FL: Florida Exotic Pest Plant Council. http://www.fleppc.org/Manage_Plans/mplan.pdf (Accessed November 2005).

Serbesoff-King, K. 2003. Melaleuca in Florida: A Literature Review on the Taxonomy, Distribution, Biology, Ecology, Economic Importance and Control Measures. Journal of Aquatic Plant Management 41:98-112.

Stocker, R.K., and D.R. Sanders. 1981. Chemical Control of Melaleuca quinquenervia. Proceedings of the Melaleuca Symposium., edited by R.K. Geiger, pp. 129-134. Tallahassee, FL: Florida Department of Agriculture and Consumer Services, Division of Forestry.

TAME Melaleuca. 2006. Melaleuca Trees Invading Islands in the Loxahatchee NWR in Palm Beach County. http://tame.ifas.ufl.edu/html/gallery/melaleuca/ 007.htm (Accessed June 2006).

\section{Acknowledgments}

This research was sponsored in part by the USDA-Agricultural Research Service, under The Areawide Management Evaluation of Melaleuca
(TAME Melaleuca). Valuable assistance was provided by Cressida Silvers and Paul Pratt (USDA-ARS); Francois Laroche, Amy Ferriter, and Sharon Wallace (South Florida Water Management District); Debbie Gillet (Southwest Florida Water Management District); Chris Wassil and Gary Lewis (Florida Division of Forestry); and Gail Baxley (Florida Department of Environmental Protection). Critical reviews of this paper were provided by Ferdinand Wirth, Sherry Larkin, and Thomas Stevens of UF/IFAS. 